\title{
Impact of $\beta$-aminobutyric acid on induced resistance in tomato plants exposed to a combination of abiotic and biotic stress.
}

\author{
Ines Ben Rejeb ${ }^{1,2}$, Victoria Pastor ${ }^{1}$, Valérie Gravel ${ }^{2}$, Brigitte Mauch-Mani ${ }^{1 *}$ \\ ${ }^{1}$ University of Neuchâtel, Laboratory of Molecular and Cell Biology, Rue Emile-Argand 11, 2009 Neuchâtel, \\ Switzerland \\ ${ }^{2}$ Department of Plant Science, Faculty of Agricultural and Environmental Sciences, McGill University, 21111 \\ Lakeshore Road, Ste. Anne de Bellevue, Québec, H9X 3V9, Canada
}

\begin{abstract}
A plant's defensive capacity can be enhanced by treatment with various synthetic and natural compounds capable of improving its immune system and make it more resistant. This is called priming. Primed plants express faster and stronger enhanced defence upon encountering either abiotic or biotic stress. Traditionally, plant stress has been studied by applying a single type of stress such as drought, salinity or infection and analysing phenotypic and molecular aspects of the resulting plant phenotype. However, this type of analysis is in sharp contrast to natural conditions where plants are simultaneously subjected to a combination of different abiotic and biotic stresses that limit crop yields. Recent evidence shows that a combination of abiotic and biotic stress can have a positive effect on plant performance by reducing the susceptibility to biotic stress. Such an interaction between both types of stress points to crosstalk between their respective signalling pathways. Using the non-protein amino acid $\beta$-aminobutyric acid (BABA) to prime tomato plants, we found that BABA-treated plants showed earlier and higher expression of $P R 1$ and $P R 5$ genes following combination of salt stress and infection with Botrytis cinerea compared to unstressed plants exposed to salt. Histochemical analysis revealed that in BABA-treated plants, induced levels of callose deposition and lignin accumulation were higher than in non-treated controls, while the spread of $B$. cinerea was strongly reduced. A rapid $\mathrm{H}_{2} \mathrm{O}_{2}$ accumulation detected in BABA-treated plants under combined stress, may have contributed to the observed decrease in the pathogen's proliferation.
\end{abstract}

Keywords: $\beta$-aminobutyric acid, Tomato, Salt stress, Botrytis cinerea, Combined stresses, Induction of resistance.

Accepted on September 14, 2018

\section{Introduction}

Tomato (Solanum lycopersicum L.) is one of the most important crops and widely cultivated around the world. In 2013 , it was seventh in the ranking of food crops worldwide, while production and consumption are constantly increasing $[1,2]$. Tomato provides valuable compounds like lycopene, known for its anti-oxidative and anticancer properties [3]. However, the yield potential of tomato is strongly affected by biotic stress factors including Botrytis cinerea [4,5]. This necrotrophic fungus induces cell death in the vegetative tissues $[6,7]$. B. cinerea penetrates through wounds or stomata and kills plant tissues by secreting toxic compounds or lytic enzymes [8]. This infection leads to necrosis of the host. Constitutive barriers, such as a stronger cell wall or stored metabolites, and inducible defenses, such as the synthesis of phytoalexins, help plants cope with such fungal attacks [9]. However, in their natural habitats, plants are often challenged not only by biotic stress but at the same time with abiotic stresses. The simultaneous action of both abiotic and biotic stressors can activate a multitude of compounds in the plant that act with different modes of convergence ensuring the regulation and the modification of the plant response pattern which could be completely different from the predicted plant responses to a single constraint [10-13].
The interaction between abiotic and biotic stresses in plant responses is controlled by different hormonal signaling pathways and by a variety of molecular mechanisms that work together in a very complex way [10,14-16]. Narusaka et al. [17] indicated that plant responses to a simultaneous abiotic and biotic stress are associated with changes in complex gene networks in order to withstand the stress. However, studies in this field suggested that abiotic stress can have additive (increasing the stress impact) or reductive (increasing stress tolerance) effects on plants upon pathogen attack and vice versa [10,18-20]. The rapid accumulation of abscisic acid (ABA) in the plants as an adaptive response to abiotic stress for example increases the susceptibility of plants to pathogen attacks [21]. Sorghum and bean stressed by drought stress present a higher susceptibility to Macrophomina phaseolina [22,23]. The same holds true for Arabidopsis exposed to drought stress and P. syringae [24]. Moreover, under salt stress, increased plant tolerance through $\mathrm{Na}^{+}$compartmentalization in the vacuoles may have adverse effects on pathogen feeding and development [12]. In contrast, in some cases the exposure of plants to abiotic stress enhances resistance to pathogen attacks $[25,26]$ via the positive effect of ABA on callose deposition $[27,28]$ and the induction of gene expression in response to both kinds of stress [29]. Drought stress enhances resistance 
against $B$. cinerea in tomato [30]. This positive interaction can be due to stomatal closure reducing water loss from infected tissues or the high levels of defense compound accumulated after a period of abiotic stress as shown in the sitiens tomato mutant where the abscisic acid deficiency increases the resistance to $B$. cinerea [31]. It is still not clear why some studies on to the combination of abiotic and biotic stresses report an increase of plant resistance against pathogen attacks while others an increased susceptibility to infection [32].

Generation of reactive oxygen species (ROS) as inducible defense response following abiotic and biotic stress depends on the strength and duration of the stress [33-35]. Low levels of ROS occur primarily as stress signal transduction molecules that insure plant acclimation against many stresses. They can, however, become toxic for plants if levels continue to increase leading to oxidative stress [36]. To minimize damage under abiotic stress conditions, plants produce antioxidant and ROSscavenging enzymes [37,38]. In contrast, plants actively generate ROS and act positively on plant resistance against pathogen infection by mediating the hypersensitive response (HR)-like cell death, a process known as the oxidative burst. In this case, the accumulation of ROS limits pathogen spread [39-41]. Furthermore, ROS accumulation in response to a combination of abiotic and biotic stress may create a stressspecific signal to both stressors in order to induce the acclimation response to the plants. Laluk et al. [42] demonstrated that Pentatricopeptide Repeat Protein for Germination on $\mathrm{NaCl}$ (PGN) controls the role of ROS in the combination of abiotic and biotic stress conditions, which indicates that PGN is responsible to regulate ROS homeostasis in the mitochondria.

Priming plants puts them into a stage where they show an increased and accelerated ability to activate various defense mechanisms upon encountering biotic and abiotic stresses $[43,44]$. Among the many inducers of resistance, $\beta$ aminobutyric acid (BABA) has proved to be an effective agent for the induction of resistance to both biotic and abiotic stressors $[45,46]$. Depending on the challenging stressor, BABA-primed plants will mount their defense via the appropriate defense signaling pathway. BABA-induced resistance against downy mildew and Pseudomonas for example depends on salicylic acid (SA) signaling leading to the accumulation of pathogenesis-related (PR) proteins while defense against necrotrophic fungi depends on ABA $[47,45]$. $\mathrm{PR}$ proteins are induced not only in response to pathogen attack but also under abiotic stress conditions [45,48-50]. Unfortunately, there is a lack of information related to BABAinduced tolerance in plants subjected to a combination of abiotic and biotic stress. The objective of this study was to determine the effect of pre-treatment of tomato plants with BABA on salt-induced predisposition to the foliar pathogen $B$. cinerea. We also evaluated the impact of BABA on the expression pattern of $\mathrm{PR}$ genes and some transcription factors involved in the defense responses to a combination of salinity and infection with $B$. cinerea.

\section{Material and methods}

\section{Culture conditions}

Controlled conditions: Seeds of tomato cultivar Marmande were obtained from Quedlinburger (Aschersleben, Germany). For sterilization, tomato seeds were rinsed in $70 \%$ ethanol, incubated for 15 minutes in $2 \%$ bleach and washed 4 to 5 times with sterile distilled water. After 24 hours at $4^{\circ} \mathrm{C}$, sterilized seeds were pre-germinated for 6 days in a Petri dish with a humid sterile Whatman filter paper in the dark in a plant growth chamber (Percival AR-95L, CLF Plant Climatics $\mathrm{GmbH}$, Wertingen, Germany). Tomato seedlings were then transferred to multi-cell growing trays filled with commercial soil (Compost (25\%), sand (12\%) and peat (63\%); Ricoter Erdaufbereitung AG, Aarberg, Switzerland) watered with Solbac (Andermatt Biocontrol, Switzerland) solution to prevent fungus gnat problems. Ten days later, seedlings were individually transferred to small $100 \mathrm{~mL}$ plastic pots filled with the same soil. All plants were well watered and kept in the same plant growth chamber with the following conditions: 16hour day at $26^{\circ} \mathrm{C}, 8$-hour night at $18^{\circ} \mathrm{C}, 60 \%$ relative humidity and an irradiance of $245 \mu \mathrm{mol} \mathrm{m} \mathrm{m}^{-2} \mathrm{~s}^{1}$ until they reached the stage of four fully expanded true leaves (from the tip, excluding petiole). At this stage, plants of uniform size were used for the experiments.

Greenhouse conditions: Seeds of tomato cultivar Marmande were sterilized and pre-germinated as described above. Tomato seedlings were then transferred to multi-cell growing trays filled with soil mixture (Compost (25\%), sand (12\%) and peat $(63 \%)$, Fafard, Canada) and further processed in a greenhouse (Plant Research Facility Greenhouse, McGill University, Canada) under the same conditions as described above for growth chamber grown plants.

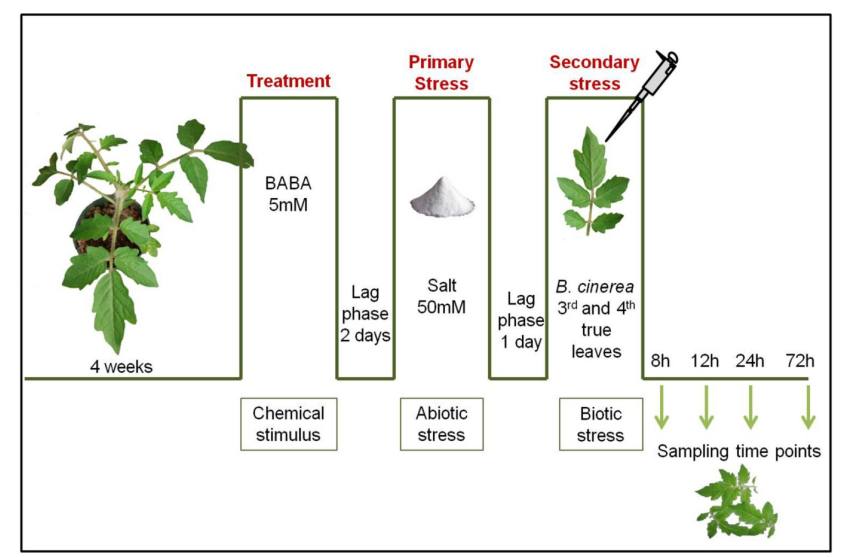

Figure 1. Time course of the combined stress experiments in BABAtreated tomato plants. Four-week-old tomato plants were exposed to a chemical stimulus, BABA, by soil drench. After two days, the primary stress 'salt stress' was applied as a soil drench. After one day, a secondary stress ' $B$. cinerea' was applied by placing $6 \mu$ droplets of the fungal suspension on the third and the fourth true leaves. Leaf tissues were harvested at four-time points: (1) after 8 hours post inoculation (hpi); (2) after 12 hpi; (3) after 24 hpi; (4) after $72 \mathrm{hpi}$. 
Citation: Rejeb IB, Pastor V, Mauch-Mani B, et al. Impact of $\beta$-aminobutyric acid on induced resistance in tomato plants exposed to a combination of abiotic and biotic stress. J Agric Sci Bot 2018;2(3):12-23.

\section{Priming and stress application}

$\beta$-Aminobutyric acid (BABA) (Sigma-Aldrich, Switzerland and Canada) was dissolved in water and applied as a soil drench (5 mM BABA final soil concentration) [51] to 4-weekold plants 2 days prior to applying salt stress $(0$ and $50 \mathrm{mM}$ $\mathrm{NaCl})$. Control plants were watered with tap water. The time point of BABA treatment is considered to be day 0 (Figure 1). Tomato plants (cv Marmande) were subjected to pre-treatments with various concentrations of BABA, followed by the salt stress 48 hours later. The inoculation with $B$. cinerea was performed after 24 hours of the salt stress.

\section{Inoculations}

B. cinerea was isolated from an infected tomato fruit and was routinely cultured on potato dextrose agar (PDA) (Difco Laboratories, Detroit, Switzerland and Canada) at $24^{\circ} \mathrm{C}$. Conidia were harvested from sporulating colonies (15-day-old cultures) with $5 \mathrm{~mL}$ of sterile water. Conidia were filtered through gauze, washed by centrifugation (10 $\mathrm{min}, 1533 \mathrm{~g}$, $20^{\circ} \mathrm{C}$ ) and centrifuged another time (4 min, $\left.13552 \mathrm{~g}\right)$. The pellet was re-suspended in $1 \mathrm{~mL}$ of sterile water and the final conidia suspension was made with $1 \mathrm{~mL}$ of $1 / 2$ strength PDB (Potato Dextrose Broth) (Difco Laboratories, Detroit) and 10 $\mu \mathrm{L}$ of sucrose (10 $\mathrm{mM}$ as a final concentration) at a density of $10^{6}$ conidia $\mathrm{mL}^{-1}$. The suspension was pre-incubated without shaking for 2 hours. Six $\mu \mathrm{L}$ droplets of the suspension were placed on the third and the fourth true leaves. All plants were transferred to a container with a transparent lid (growth chamber) or covered with transparent plastic bags (greenhouse) to keep $100 \%$ of relative humidity. These experiments were repeated two times with similar results.

\section{Size of infected area}

Seventy-two hours after inoculation, the area of infection was calculated by measuring with a caliper square (two diameter values for each infection site) and the infected leaves were directly put into $100 \%$ ethanol for later callose staining. Average sizes of infection were based on at least 20 measurements from six tomato plants. Six biological replicates were collected.

\section{Callose staining}

Seventy-two hours after inoculation, tomato leaves were collected, discolored in 95\% EtOH and stained with anilineblue (Sigma Aldrich, Switzerland) as described previously by Ton et al. [45], with some modifications. Briefly, leaves were incubated for at least $24 \mathrm{~h}$ in $100 \%$ ethanol until all tissues were transparent, washed in $0.07 \mathrm{M}$ phosphate buffer $(\mathrm{pH}=9)$, and incubated for 1 to $2 \mathrm{~h}$ in $0.07 \mathrm{M}$ phosphate buffer containing 0.01\% aniline-blue (Sigma Aldrich, Switzerland), prior to microscopic analysis. Observations were performed with an epifluorescence microscope with UV filter (BP 340 to $380 \mathrm{~nm}$, LP $425 \mathrm{~nm}$ ). Callose was quantified from digital photographs by the number of white pixels (callose intensity) or the number of depositions relative to the total number of pixels covering plant material, using Image $J$ software. Callose was selected automatically, using the "Color Range" tool. The accuracy of resulting callose selection was visually verified before proceeding. Average callose measurements were based on at least 20 photographs from different tomato plants. Six biological replicates were collected.

\section{Gene expression}

Plant material was harvested at $0 \mathrm{~h}, 8 \mathrm{~h}, 12 \mathrm{~h}$, and $24 \mathrm{~h}$ after inoculation with $B$. cinerea, flash frozen in liquid nitrogen and kept at $-80^{\circ} \mathrm{C}$ until use. Three biological replicates were collected per time point.

\section{RNA extraction and gene expression analysis}

Total RNA was extracted from the frozen tomato leaf tissues. RNA isolation was performed according to manufacturer's instructions using the RNeasy Plant Mini kit (Qiagen, http:// www.qiagen.com). RNA was treated with DNase (Qiagen) and reverse transcribed into cDNA using SuperScript III RT (Invitrogen, http://www.invitrogen.com).

Table 1. Primers used to assess transcription factor and gene expression in tomato leaves under combination of abiotic and biotic stress.

\begin{tabular}{|c|l|l|l|l|}
\hline Stress & \multicolumn{1}{|c|}{ Gene } & \multicolumn{1}{|c|}{ Accession } & \multicolumn{1}{|c|}{ Fw primer } & \multicolumn{1}{c|}{ primer } \\
\hline Drought & CBF3 & AY497899 & CTGTTTTCCATGCCAGGATT & GGGGAGGAGGTAGCATGAG \\
\hline Drought & AREB & EU_001247667 & TGGTGAAACTGTTATTCAGTCTGC & TTGCTTCTCATCAACCCACA \\
\hline Biotic stress & PR1 & NM-001247422 & GTGAATGCCCTGGTTCACTT & TCCGAATGTAGTACAAGGGTTG \\
\hline Biotic stress & PR5 & XM_004249818 & GGTTGGAATGGGTCAGAAAG & GATACCCCTCTTGGATTGAGC \\
\hline Reference gene & Actin-7-like & NM_001247878.2 & TACTGAAGGCGCAGAGTTGA & TTCTCCGCTTCTTTACGAACA \\
\hline Reference gene & Tubulin & &
\end{tabular}

Primers for qRT-PCR were designed using the universal probe library assay design tool from Roche. The genes and their corresponding primers used in this study are listed in Table 1. Primer efficiency was determined by performing a qRT-PCR with serially diluted cDNA. Minimal accepted efficiency for the primers was set to 0.8 . The qRT-PCR was performed using the SensiMix SYBR kit (Bioline, http://www.bioline.com) on a Rotor-Gene 6000 cycler (Qiagen). The reaction volume was 10 $\mu \mathrm{L}$, consisting of $2.5 \mu \mathrm{L}$ nuclease-free water, $5 \mu \mathrm{L}$ SensiMix SYBR mastermix, $0.25 \mu \mathrm{L}$ forward and reverse primer (each 
$10 \mu \mathrm{M})$ and $2 \mu \mathrm{L}$ cDNA. PCRs were performed using 3 independent biological replicates per sample, each replicate consisting of a pool of 3 plants. PCR reactions were performed in technical duplicates as a three-step reaction (initial hold step, $95^{\circ} \mathrm{C}$ for $10 \mathrm{~min} ; 40$ cycles of amplification, $95^{\circ} \mathrm{C}$ for $15 \mathrm{~s}$, $60^{\circ} \mathrm{C}$ for $20 \mathrm{~s}, 72^{\circ} \mathrm{C}$ for $20 \mathrm{~s}$ ) with a final melting curve analysis $\left(68^{\circ} \mathrm{C}-95^{\circ} \mathrm{C}\right)$. Melting curve and cycle threshold $(\mathrm{Ct})$ analysis were performed on the Rotor-Gene 6000 software 1.7. Relative gene expression of stressed tissue was calculated relative to control treated plants in regard to the two housekeeping genes Actin and Tubulin and the specific primer efficiencies with the help of REST 2009 (Qiagen).

\section{DAB staining, microscopy analysis, and $\mathrm{H}_{2} \mathrm{O}_{2}$ quantification}

In situ hydrogen peroxide $\left(\mathrm{H}_{2} \mathrm{O}_{2}\right)$ production was revealed by brown precipitates after 3,3'-diaminobenzidine (DAB) staining. The $3^{\text {rd }}$ and the $4^{\text {th }}$ fully expanded leaves at $72 \mathrm{hpi}$ were cut into discs $(0.5 \mathrm{~cm}$ in diameter $)$. Harvested leaf discs were stained in $1 \mathrm{mg} \mathrm{mL}^{-1}$ of DAB (Sigma Aldrich, Canada) at $\mathrm{pH}<3$, put for $24 \mathrm{~h}$ in the dark and subsequently destained in saturated chloral-hydrate (Sigma, Canada), as described previously $[52,53] . \mathrm{H}_{2} \mathrm{O}_{2}$ is visualized as a reddish-brown deposit in DAB-treated leaves. DAB staining intensities were quantified from digital photographs (Zeiss stereo discovery v20 microscope (Carl Zeiss Canada ltd., Toronto, Ontario, Canada)) by the number of dark-brown DAB pixels relative to total pixels corresponding to plant material, using Image J. Six biological replicates were collected for analysis and average of ROS measurements were based on at least 20 photographs from different tomato plants.

\section{Histochemical analysis of lignin}

Histochemical determination of lignin was performed using Wiesner's test. The $3^{\text {rd }}$ and the $4^{\text {th }}$ fully expanded leaves were cut into discs at $72 \mathrm{hpi}$. Discs were treated with a saturated solution of phloroglucinol (Sigma Aldrich, Canada) in $85 \%$ $(\mathrm{v} / \mathrm{v})$ ethanol, for $3 \mathrm{~min}$ at room temperature and washed in $25 \%(\mathrm{v} / \mathrm{v}) \mathrm{HCl}[54,55]$. Lignin was visualized as a pink color around the infection site. Pictures of lignin were taken under a Zeiss stereo discovery v20 microscope (Carl Zeiss Canada ltd., Toronto, Ontario, Canada).

\section{Statistical analysis}

Significance of differences between control and treated plants was analyzed with a two-way ANOVA; control and stressed plants $(\mathrm{P}<0.05)$ were then compared using the Tukey's range and t-test. All statistical analyses were accomplished using Sigma Plot 11.0 (http://www.sigmaplot.com).

\section{Results}

\section{Disease progress in leaves}

The objective of this experiment was to evaluate the effect of BABA on the induction of resistance in plants subjected to a combined stress in two different, namely controlled (growth chamber) and semi-controlled (greenhouse) conditions. Progress of the disease differed between cv Marmande plants treated and non-treated with BABA and stressed or not with salt (Figures 2 and 3). Compared with non-treated control plants, BABA-treated cv Marmande plants showed a statistically significant reduction in lesion size at $72 \mathrm{~h}$ after combined stress in both conditions (Figure 2). The effect of BABA on the proliferation of $B$. cinerea in the abscisic acid (ABA)-deficient sitiens tomato mutant (Figures S2 and S3) was better than the results obtained with cv Marmande, under semi-controlled conditions which sitiens exhibited a higher level of resistance against $B$. cinerea (Figure 2). The size of infections in the sitiens mutant was smaller compared to both cv Rheinlands Ruhm and cv Marmande. In addition, concomitant treatment with BABA and $50 \mathrm{mM}$ of salt lead to a higher protection against $B$. cinerea compared to non-treated and stressed cv Marmande plants. This induction of resistance was also reflected by a statistically significant reduction of the infection size, but there was no significant difference between control plants treated with BABA and plants treated with $\mathrm{BABA}+50 \mathrm{mM}$ of salt which still looked healthy under controlled and semi-controlled conditions (Figure 3).
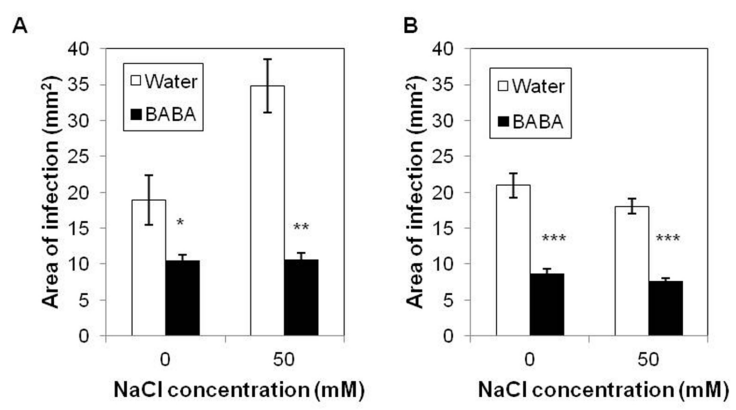

Figure 2. Size of lesions caused by B. cinerea infection $72 \mathrm{~h}$ postinoculation of tomato leaves (cv Marmande) treated with water or $B A B A$ and then challenged with abiotic stress (salt stress: water control and $50 \mathrm{mM} \mathrm{NaCl).} \mathrm{A)} \mathrm{Size} \mathrm{of} \mathrm{infection} \mathrm{area} \mathrm{in} \mathrm{tomato} \mathrm{grown}$ under controlled conditions. B) Size of infection in tomato from greenhouse conditions. Data shown are average values $( \pm$ standard error of the mean; $n>6$ independent replicates) of relative area. Asterisks indicate significant differences (Student's $t$-test, $p<0.001$ ) in the area of infection between plants treated with water and plants treated with $B A B A$. The experiment was repeated 2 times with similar results. $(*=p<0.05, * *=p<0.01, * * *=p<0.001)$.

However, plants subjected to 100 and $200 \mathrm{mM}$ of salt, respectively, were severely infected by the fungus, independently if they had been treated with BABA or not under controlled conditions (Figure S1). This suggests that high salt concentrations (100 and $200 \mathrm{mM}$ ) were toxic to the plants and BABA was not able to protect them under these severe conditions.

\section{Localization and intensity of callose deposits induced by $B$. cinerea}

To investigate the role of stress combination (salt stress and inoculation with $B$. cinerea) on BABA-induced callose, we examined the dynamics of callose accumulation in BABA- 
Citation: Rejeb IB, Pastor V, Mauch-Mani B, et al. Impact of $\beta$-aminobutyric acid on induced resistance in tomato plants exposed to a combination of abiotic and biotic stress. J Agric Sci Bot 2018;2(3):12-23.

primed and non-primed plants in response to a stress combination (Figures 4 and S4). We did find a statistically significant increase in callose deposition upon concomitant treatment with BABA and the combination of two stresses compared to plants treated with BABA and just a single stress (inoculation with $B$. cinerea; Figure 4). These results suggest that callose induction in BABA-treated plants was improved by the simultaneous application of two stresses. However, in the case of water-treated control plants, there was a significant difference between plants subjected to a single or double stress with a lower level of callose detected upon stress combination.

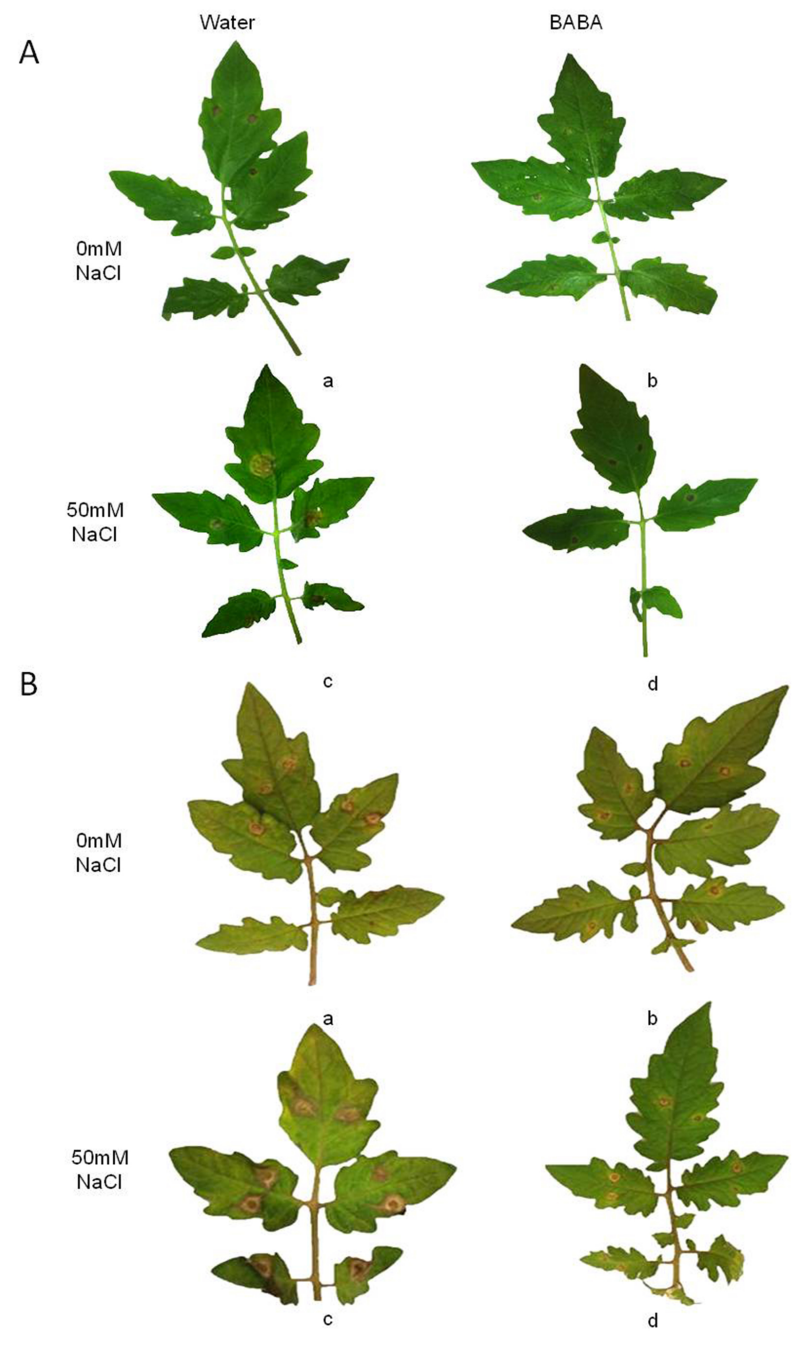

Figure 3. Responses of tomato plants (cv Marmande) treated with water or BABA to the combination of salt stress $(50 \mathrm{mM})$ and $B$. cinerea. A) Leaves from tomato plants subjected to combined stresses, experiment was conducted under controlled conditions: Leaves treated with water or BABA (representative of two replicate treatments) from control ( $a$ and b) and stressed with $50 \mathrm{mM}$ of salt (c and d). B) Leaves from tomato plants subjected to combined stresses, experiment was conducted under greenhouse conditions: Leaves treated with water or $B A B A$ (representative of two replicate treatments) from control ( $a$ and b) and stressed with $50 \mathrm{mM}$ of salt (c and d). Symptoms photographed $72 \mathrm{~h}$ post-inoculation.

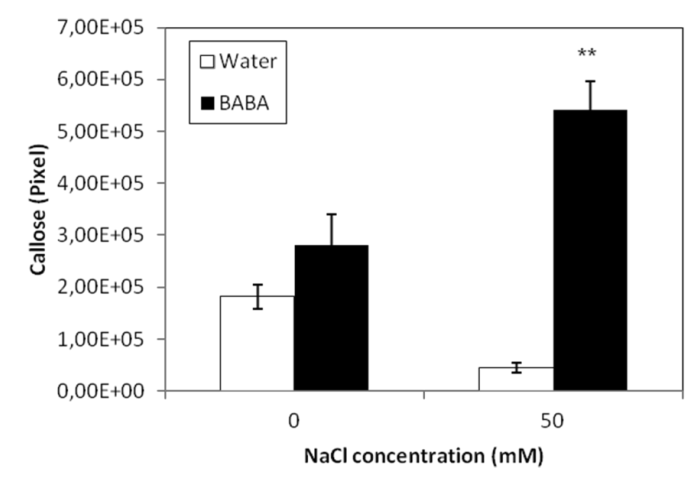

Figure 4. Callose deposition in tomato leaves in response to $B$. cinerea infection in water or BABA-treated plants additionally exposed or not to salt stress $(50 \mathrm{mM})$. Data shown are average values ( \pm standard error of the mean; $n>20$ ) of relative callose intensities at 72 hpi with B. cinerea. Asterisks indicate statistically significant changes in response to $B A B A$ treatment and combined stress (Student's t-test; $\alpha=0.05)$. $(p=0.0272)$.

\section{Involved defense signaling pathways}

In order to assess the effect of BABA treatment and saline stress on $B$. cinerea resistance at the transcriptomic level, we evaluated the expression of a chosen set of genes and transcription factors $\left(\mathrm{TF}_{\mathrm{S}}\right)$ known to be involved in the induction of salinity tolerance and/or $B$. cinerea resistance (Table 1; [56-59]). The expression of tomato defense genes was studied to determine the cross-talk between abiotic (low salinity $(50 \mathrm{mM}))$ and biotic stress (B. cinerea) and also the defense pathways affecting both kinds of stressors (Figure 5). Control infected tomato plants at $8 \mathrm{hpi}$ presented no significant differences between plants treated or not with BABA for all genes tested except PR1, which was slightly down-regulated. Interestingly, at the same time, BABA induces ABAresponsive element-binding proteins (AREB) and C-repeat binding factors 3 (CBF3) expressions after combination of salt stress $(50 \mathrm{mM})$ B. cinerea, contrary to PR1 and PR5 that were down-regulated. This suggests that at this initial phase of colonization, only $\mathrm{TF}_{\mathrm{s}}$ related to abiotic stress (AREB and CBF3) were activated. Twelve hours post infection the comparison between plants treated or not with BABA under single stress (infection with $B$. cinerea) showed an upregulation in the expression of $\mathrm{CBF} 3$ and $\mathrm{PR} 1$. This shows that BABA has a positive effect on the expression of $\mathrm{CBF} 3$ and PR1 in plants infected with $B$. cinerea. Surprisingly, CBF3 was down-regulated after $12 \mathrm{hpi}$ in plants treated with BABA and subjected to double stress. In addition, PR1 and PR5 were upregulated at 24 hpi in BABA-treated plants under combined stress. PR1 and PR5 expressions were induced in plants treated with BABA under combined stress and were expressed higher than under single. 

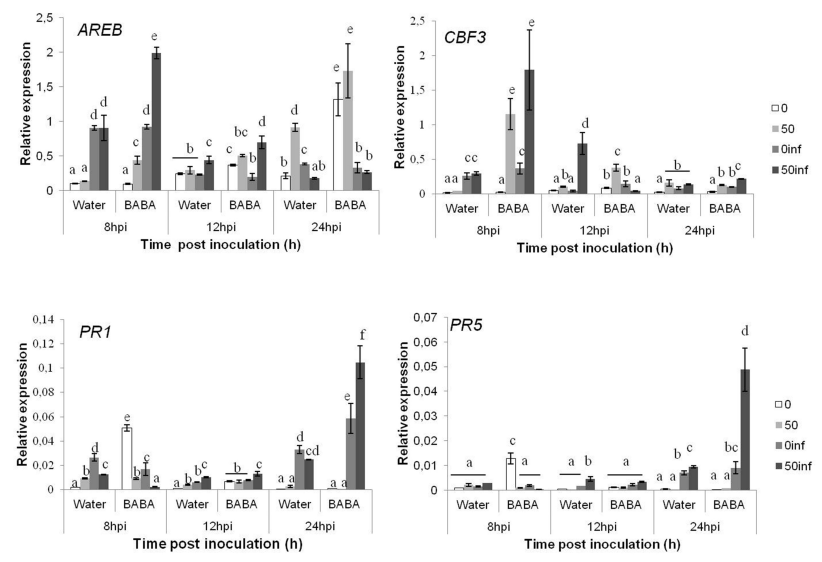

Figure 5. Comparative analysis of defense gene and TF expression in tomato leaves (cv Marmande) stressed with or without $50 \mathrm{mM}$ of $\mathrm{NaCl}$ and infected with B. cinerea at 8, 12 and 24 hpi. Quantitative reverse-transcription polymerase chain reaction ( $q R T-P C R)$ analysis of AREB, CBF3, PR1, and PR5 in 4-week-old tomato plants pretreated with $\beta$-aminobutyric acid (BABA) 1 day before salt stress and 2 days before infection with Botrytis cinerea. RNA was isolated from leaves at $0,8,12$ and $24 \mathrm{~h}$ after inoculation, converted to cDNA and the analyzed by $q R T-P C R$. Bars represent mean \pm standard deviation (SD), $n=3$ independent replicates (Fisher's least significant differences test; $\alpha=0.05$ ).

\section{Impact of stress on $\mathrm{H}_{2} \mathrm{O}_{2}$ accumulation and positive effect of $B A B A$ treatment}

A possible involvement of ROS in the response of plants subjected to combined abiotic and biotic stress was addressed. To this end, leaves of treated plants were subjected to DAB staining and $\mathrm{H}_{2} \mathrm{O}_{2}$ accumulation at the inoculation site was quantified digitally after $24 \mathrm{~h}$ of staining. Control and stressed leaves from tomato plants (cv Marmande) treated with BABA exhibited higher staining at the inoculation site than leaves from water controls (Figure 6). Further, this result was confirmed by quantification of $\mathrm{H}_{2} \mathrm{O}_{2}$ accumulation (Figure 6) where the accumulation of $\mathrm{H}_{2} \mathrm{O}_{2}$ was significantly higher in leaves of plants treated with BABA compared with non-treated plants. This confirms that BABA positively influences ROS accumulation in situ. In non-treated plants, a heavy staining was observed in the presence of salt stress. The $\mathrm{H}_{2} \mathrm{O}_{2}$ levels were higher in stressed plants compared to the control. A combination of salt stress and inoculation with $B$. cinerea increased $\mathrm{H}_{2} \mathrm{O}_{2}$ accumulation compared to plants under single stress $(B$. cinerea). Surprisingly, there was no significant difference of $\mathrm{H}_{2} \mathrm{O}_{2}$ accumulation in BABA-treated plants under double or single stress $(\mathrm{p}=0.0966)$. In addition, $\mathrm{H}_{2} \mathrm{O}_{2}$ accumulation was significantly higher under combined stress in BABA-treated sitiens and its wild-type compared to nontreated plants Moreover, $\mathrm{H}_{2} \mathrm{O}_{2}$ levels were higher under combined stress in BABA-treated plants than under single stress and it was observed that this level was higher in the sitiens mutants compared to its wild-type and cv Marmande (Figure S5). These results may be connected to the effect of ABA in all defense responses in plants under single or double stress.
A

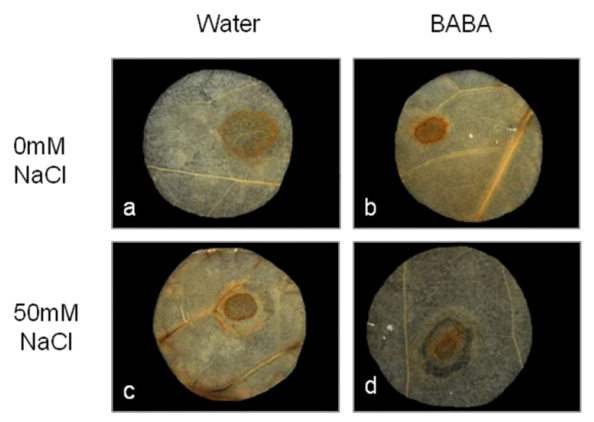

B

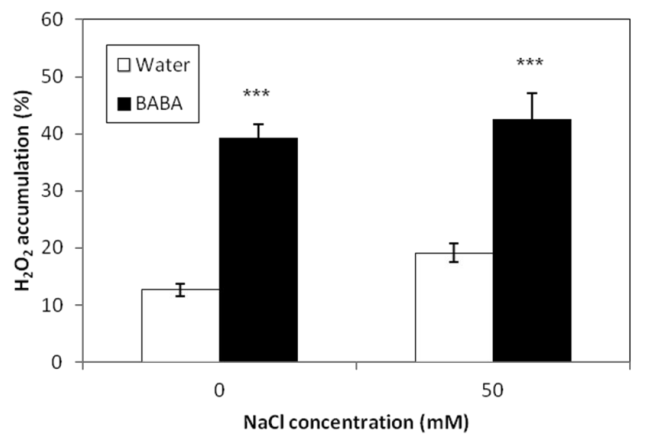

Figure 6. Impact of stressed conditions on $\mathrm{H}_{2} \mathrm{O}_{2}$ accumulation in leaves to 30 day-old tomato plants ( $c v$ Marmande) treated with water or BABA (5 mM) $48 \mathrm{~h}$ before exposing them to salt stress. The results are expressed as percentage of dark-brown spots coloration relative to the total leaf disc surface ( \pm standard error of the mean; $n>20$ ) at 72 hours after infection. A) Photographs of stained leaf discs. Photographs show stained leaf discs with 3,3-diaminobenzidine (DAB) at 72 hours post inoculation (hpi) and analyzed by light microscopy. a) Nontreated control inoculated with B. cinerea; b) $B A B A$-treated tomato plants and inoculated with $B$. cinerea; $c$ ) Nontreated stressed plants and inoculated with B. cinerea; d) BABAtreated tomato plants and subjected to a combination of salt and inoculated with $\mathrm{B}$. cinerea. $\mathrm{B}) \mathrm{H}_{2} \mathrm{O}_{2}$ accumulation in treated or nontreated tomato plants under combination of abiotic and biotic stress. Asterisks indicate statistically significant differences between salt stressed and water or BABA-treated plants (Student's t-test; $\alpha=0.05$ ). The experiment was repeated twice with similar results. $(* * *=p<0,001)$.

\section{Lignin deposition around the infection sites}

BABA-treated tomato plants stressed by salt and infected with B. cinerea were stained with phloroglucinol- $\mathrm{HCl}$ to visualize lignification in the tissues. A strong accumulation of lignin was observed in BABA-treated tomato plants in both control and stressed plants compared to non-treated plants (Figure 7). However, there was no difference in lignin accumulation in BABA-treated plants under single or double stress. This confirms that BABA helps to increase lignification and therefore induce resistance to biotic stress and combination of abiotic and biotic stress. Similar results were obtained with cv Rheinlands Ruhm tomato plants and the sitiens mutant where plants treated with BABA presented a more pronounced staining under single and combined stress compared to watertreated plants (Figure S6). 
Citation: Rejeb IB, Pastor V, Mauch-Mani B, et al. Impact of $\beta$-aminobutyric acid on induced resistance in tomato plants exposed to a combination of abiotic and biotic stress. J Agric Sci Bot 2018;2(3):12-23.

Water
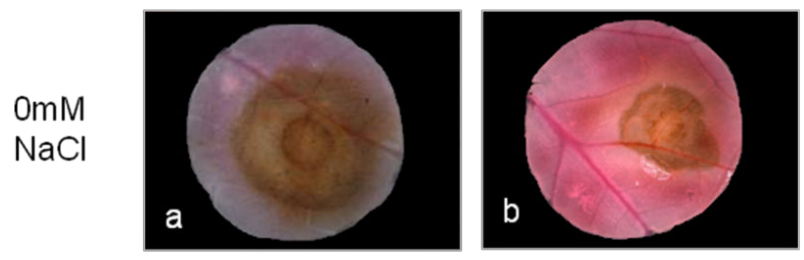

$50 \mathrm{mM}$

$\mathrm{NaCl}$
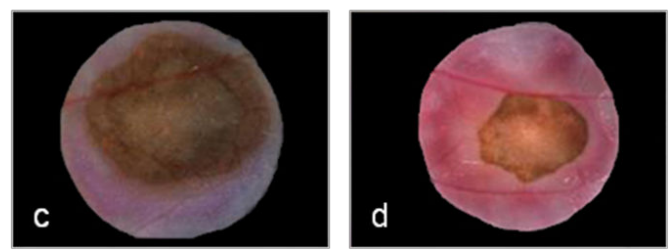

Figure 7. Photographs of lignin deposition in leaf discs of tomato ( $\mathrm{cv}$ Marmande) from the third and fourth true leaves treated with water or BABA followed by a combination of salt stress $(50 \mathrm{mM})$ and infection with $B$. cinerea. a) through d), leaf disks $(0.5 \mathrm{~cm}$ in diameter) of tomato. a) Water controls inoculated with B. cinerea; $b$ ) Water-treated, salt-stressed plants, inoculated with $B$. cinerea; $c$ ) BABA-treated plants inoculated with B.cinerea; d) BABA-treated plants subjected to salt stress and inoculated with $B$. cinerea.

\section{Discussion}

The goal of the study was to evaluate the effect of BABA treatment on the defensive capacity of tomato plants exposed to a combination of biotic and abiotic stress. For the biotic stress we used the grey mold pathogen $B$. cinerea, a necrotrophic fungus, and mild abiotic stress was achieved through soil drench with $50 \mathrm{mM} \mathrm{NaCl}$ solution. Our results shown that exposure to salt does not negatively interfere with BABA-induced induction of resistance against grey mold. Similar results have been reported in tomato plants treated with the resistance inducers Benzothiadiazole-S-methyl ester BTH and N-(3-chloro-4-methylphenyl)-4-methyl-1,2,3thiadiazole-5-carboxamide TDL, [60] to a combination of salt stress and infection with Pseudomonas syringae $p v$ tomato [61]. These results contradict earlier findings of Yasuda et al. [62] that showed that exogenous ABA (simulating the effect of abiotic stress on plants) suppressed the induction of systemic acquired resistance (SAR) induced by 1,2-benzisothiazol-3 (2H)-one-1,1-dioxide BIT or BTH [63,60] in Arabidopsis plants infected with Pseudomonas syringae $p v$ tomato. Interestingly, under mild salt stress $(50 \mathrm{mM})$ the average size of necrotic lesions was significantly larger than in watertreated control plants. These results are in agreement with some studies reporting a negative impact of abiotic stress on disease resistance $[62,12,64]$. Previous reports have shown that ABA, which is induced during abiotic stress, increases plant susceptibility to many fungi. Treatment with ABA reduced the resistance of potato tuber slices against Phytophthora infestans and Cladosporium cucumerinum [65]. Similarly, the increase of susceptibility was demonstrated in rice treated with ABA and infected with Magnaporthe grisea [66].

Contradictory to our observations, relatively mild salt-stress on tomato plants was shown to have no effect on B. cinerea [30]. Thaler and Bostock [67] likewise demonstrated that salt stress did not affect tomato plant resistance to $P$. syringae. In contrast to the above report, it was found that drought stress was responsible to delay powdery mildew disease development in Alliaria petiolata (garlic mustard), which could be due to stomatal closure that reduces the ability of the pathogen to penetrate into the leaf $[67,68]$. The high resistance of the BABA-treated ABA deficient sitiens mutant of tomato against $B$. cinerea compared to its wild-type and cv Marmande suggests that the lower concentration of ABA in sitiens is correlated to the increased resistance against the necrotrophic fungus.

The $\beta$-1,3-glucan polymer callose is considered a strong physical barrier against pathogen penetration [59,69]. It is deposited in the form of papillae at the sites of attempted fungal penetration. This defense mechanism of the plants is enhanced after priming [12]. Lignin is an important phenolic polymer that participates in the formation and rigidity of cell walls. The induction of lignin-like deposits by BABA has been shown to be correlated to enhanced resistance against fungi [70,71]. Our results show that the increase of callose deposition and lignin accumulation at the cellular level could contribute to preventing the infection of $B$. cinerea in BABAtreated plants. Both callose deposition and lignin accumulation were more pronounced in BABA-treated than in water-treated tomato plants. Moreover, lignin accumulation was strongly induced in ABA-deficient BABA-treated sitiens mutants. Callose deposition and lignin accumulation might restrict penetration and development of $B$. cinerea in BABA-treated plants, correlating with the increase of resistance in tomato plants against $B$. cinerea. In support of our data, Pastor et al. [69] demonstrated that treatment with BABA induced priming of callose and decreased disease symptoms caused by Plectosphaerella cucumerina. An increase of callose deposition in Arabidopsis plants treated with BABA before infection with Alternaria brassicicola or P. cucumerina has also been shown [47,72]. Our results are in line with the observation of Hamiduzzaman et al. [71] where callose deposition and lignification were more pronounced in BABAtreated than in water-treated grapevine. In addition, concomitant treatment with BABA and $50 \mathrm{mM}$ of salt lead to a higher accumulation of callose compared to water-treated plants and also compared to BABA-treated plants. This shows that $50 \mathrm{mM}$ of salt increased resistance against $B$. cinerea in BABA-treated plants, suggesting that plants exposed to the combination of abiotic and biotic stress reacts more strongly to BABA treatment than plants exposed to single stress. As reported in previous studies, the application of ABA has a similar effect as BABA on the increase of callose deposition and consequently can be implicated in the induction of plant resistance upon pathogen attack $[47,73,27]$.

Callose deposition was however significantly affected by a combination of salt and infection with $B$. cinerea in watertreated tomato plants, suggesting that salt stress may have an additive effect on a plant's response to $B$. cinerea. In support of our data, Wiese et al. [74] found a positive role for ABA in plant-pathogen resistance, where ABA-treated barley primed for papillae-mediated resistance against powdery mildew. 
Similar results were found in tomato plants under a combination of salt stress and powdery mildew [64], where abiotic stress increased plant susceptibility to biotic stress. Contrary to our results, previous studies reported that treatment with ABA, a regulator of plant responses to abiotic stress, triggers callose-mediated resistance against necrotrophic pathogens $[75,76,47]$.

Plants respond differently to multiple stresses compared to individual stress, and in this context, we studied the effect of gene expression levels in primed plants under a stress combination. Transcription factors like AREB and CBF3 are major transcriptional activators that regulate $\mathrm{ABA}$-dependent gene expression and increased abiotic stress tolerance [77-80]. Our transcriptional analysis of some marker genes involved in abiotic stress has shown an up-regulation of AREB and CBF3 expression in BABA-primed plants at $8 \mathrm{hpi}$ and subjected to combined stress compared to non-primed plants. On the opposite, the expression of the genes involved in biotic stress (PR1 and PR5) was down-regulated. Salt-stressed and infected plants did not favor biotic stress resistance which may have increased the defense response against abiotic stress, at this stage. At this early time point ( $8 \mathrm{hpi}$ ), BABA-induced AREB and $\mathrm{CBF} 3$ expression may contribute to enhanced resistance in coordination with reduced expression of PR1 and PR5 in plants under combined stress. In this context, it is worth mentioning that AREB and CBF3 were both up-regulated, contributing to the plant induced-resistance against salt stress. Overexpression of AREB1 was shown to induce drought tolerance in Arabidopsis, rice and soybean [57,81-83]. Plants including tomato, tobacco, and wheat overexpressing DREB1/CBF, under abiotic stress, showed an increase of stress-responsive gene expression in order to induce stress tolerance $[84,85]$. A similar result was found in transgenic plants where the overexpression of DREB1/CBF3 led to increased tolerance to abiotic stress such as salinity [86,87]. Over-expression of abscisic acid-responsive element binding protein 1 identified in tomato (SlAREB1) transcripts in tomato and $\mathrm{CBF} 3$ in transgenic oats conferred resistance to salt stress and is responsible to activate defense-related genes [88,89]. This is in line with $A R E B 1$ and $C B F 3$ expression which showed upregulation in response to drought stress in leaf and root tissues of five grape varieties, which are responsible to increase stress tolerance [90]. In BABA-treated plants, the pathogenesisrelated genes PR1 and PR5 were up-regulated at $24 \mathrm{hpi}$, especially under stress combination (Figure 5). This could be related to the onset of plant protection against $B$. cinerea. Similar results were found in tomato plants treated with BTH, where PR1 was enhanced and contributed to plant protection against $B$. cinerea [31]. Surprisingly, AREB and CBF3 were suppressed in BABA-treated plants under combined stress at $24 \mathrm{hpi}$. This is probably due to BABA being responsible for a higher accumulation of ROS, and, as a consequence, better protection against B. cinerea [69]. Previous studies demonstrated that the PR proteins are induced not only following pathogen attack but also in response to abiotic stress conditions [91]. BABA-primed plants show an induction of the expression of salicylic acid-dependent (PR1,PR5) and ABAdependent (rab-related gene 18 (RAB18), responsive to dessication 29 A (RD29A)) genes upon salt stress [48,45]. Several studies reported that endo-1,3- $\beta$ glucanase, which belongs to the PR protein family, contributed to plant defense against salinity [92] and drought [49,50]. The highest increased expression of PR 1 and $\mathrm{PR} 5$ in $50 \mathrm{mM} \mathrm{NaCl}+B$. cinerea in BABA-treated plants at $24 \mathrm{hpi}$ compared to single stress (infection with $B$. cinerea) could be related to salt stress. Recently, Chojak-Kozniewska et al. [93] showed that the upregulation of PR1 in cucumber plants exposed to stress combination resulted from SA-independent induction by salt stress. Other studies have demonstrated that the induction of PR genes upon abiotic stress could probably be the consequence of an establishment of a complex signaling crosstalk between abiotic and biotic stress responses [94].

Interestingly, BABA is able to induce stress combination resistance in tomato plants and the observed priming for the induction of PR expression is in agreement with the significantly smaller average area of necrotic lesions in leaves of plants pre-treated with BABA under stress combination compared to non-treated stressed plants. Recently, Thevenet et al. [95] found that BABA is a natural product of plants and endogenous levels of BABA increase directly after pathogen attack or abiotic stress. Moreover, the increase of endogenous BABA levels after infection depends on the plant's immune system [96]. These findings can explain the importance of the effectiveness of BABA against a wide range of stresses including the combination of abiotic and biotic stress.

Increased ROS production is a common characteristic of cells exposed to a wide range of stresses. Plants have evolved the ability to take advantage of these molecules to defend themselves against abiotic and biotic stress. ROS have a dual beneficial role depending on the type of pathogen that attacks the plants. On the one hand, against biotrophic pathogens, they act as a key defense compound but on the other hand, ROS serve as the molecules helping the necrotrophic pathogen to exploit these responses [4]. In both cases, the accumulation of ROS can be effective in hindering pathogen proliferation. Here, we show that the high level of resistance to the necrotroph $B$. cinerea in tomato plants treated with BABA was partially due to an increase of $\mathrm{H}_{2} \mathrm{O}_{2}$ accumulation at the site of infection. ROS increasing directly after the pathogen attack acts as second messengers in order to induce cellular defense responses [97]. In addition, a reduced capacity to scavenge pathogen-inducible ROS contributes to reinforce and modify the cell wall, which is known to form the physical barriers against the progress of $B$. cinerea [4,98,99]. However, decreased resistance of salt-stressed tomato plants to $B$. cinerea may suggest that abiotic stresses increase susceptibility to necrotrophic pathogens in non-treated tomato plants. A contradictory result shows that there is a positive link between $\mathrm{ABA}$ and ROS to increase resistance against $B$. cinerea [100]. Others have shown that ABA treatment could induce the resistance of Arabidopsis against $B$. cinerea [29]. It can be concluded that the interaction of abiotic and biotic stress is complex but BABA has the power to induce resistance against these stressors. Pastor et al. [69] demonstrated that BABA-IR against $P$. cucumerina in Arabidopsis thaliana was dependent 
Citation: Rejeb IB, Pastor V, Mauch-Mani B, et al. Impact of $\beta$-aminobutyric acid on induced resistance in tomato plants exposed to a combination of abiotic and biotic stress. J Agric Sci Bot 2018;2(3):12-23.

on $\mathrm{H}_{2} \mathrm{O}_{2}$ accumulation. Mutants $\mathrm{NADPH} /$ respiratory burst oxidase protein $\mathrm{D}(\mathrm{rbohD})$ and phytoalexin-deficient $2(\operatorname{pad} 2)$ (mutant in ROS generation or scavenging) are impaired in BABA-induced priming of $\mathrm{H} 2 \mathrm{O} 2$ accumulation, and consequently decreased $P$. cucumerina susceptibility [69]. We demonstrate that in BABA-treated and stressed plants the accumulation of $\mathrm{H}_{2} \mathrm{O}_{2}$-dependent-defenses was tend to be higher compared to control treated plants, despite that there is no significant difference. We hypothesize that salt, which is known to increase ABA, and ROS accumulation are interconnected components to increase the capacity of BABAinduced resistance against $B$. cinerea. A similar result was presented by Ton and Mauch-Mani [47] where the induction of resistance by BABA in Arabidopsis against $A$. brassicicola and $P$. cucumerina was mediated by ABA. Thus, we can conclude that there is an establishment of a link between BABA, ABA and ROS to increase resistance against $B$. cinerea. In contrast, in BABA-treated tomato, the ABA-deficient sitiens mutant presented a higher level of resistance than the wild-type to $B$. cinerea, which coincided with a rapid accumulation of $\mathrm{H}_{2} \mathrm{O}_{2}$ under single or double stress (Figure S5). Furthermore, sitiens presented also a higher $\mathrm{H}_{2} \mathrm{O}_{2}$ concentration comparing to $\mathrm{cV}$ Marmande. Despite the number of studies examining the influence of ABA on the response of plants to pathogen attack, more research is needed to clarify these controversial results.

$\mathrm{H}_{2} \mathrm{O} 2$ accumulation was higher in water-treated sitiens mutants than its wild-type and cv Marmande. Similar results were found in the study of Asselbergh et al. [4] where $\mathrm{H}_{2} \mathrm{O}_{2}$ accumulation was higher in sitiens mutants than in wild-type plants ensuring a direct fungitoxic effect on the pathogen. In this case, $\mathrm{H}_{2} \mathrm{O}_{2}$ induced an oxidative burst and HR-like response in sitiens that may play an important role in defense signaling. Taken together, it is possible that ABA deficiency in the sitiens mutant represents an adequate defense against $B$. cinerea. Strikingly, $\mathrm{H}_{2} \mathrm{O}_{2}$ accumulation increased in sitiens mutant plants treated with BABA and under combined stress and $\mathrm{H}_{2} \mathrm{O}_{2}$ levels were higher than under single stress. Based on these results, we hypothesize that BABA and salt stress proceed together to increase $\mathrm{H}_{2} \mathrm{O}_{2}$ accumulation in the sitiens mutant.

The increase of $\mathrm{H}_{2} \mathrm{O}_{2}$ levels in plants under stress conditions may be harmful to the plants and affect the redox status and turn to oxidative stress [101]. However, in this case, the earlier accumulation of ROS always remained within adequate concentration and under what would be a toxic level for plant cell $[102,69]$.

\section{Conclusion}

BABA is well known as a priming inducer boosting the defensive response capacity of a plant against stress, but as mentioned previously, there are limited studies about the role and the mode of action of BABA to induce combined stress tolerance in plants. Here, we conclude that BABA has the capacity to induce resistance in tomato plants under a combination of salt stress and infection with $B$. cinerea. However, a negative interaction was observed in water-treated tomato plants under combined stress. BABA primed for an increase in callose deposition, lignification, and $\mathrm{H}_{2} \mathrm{O}_{2}$ accumulation in order to improve plant performance under combined stress and especially to increase pathogen resistance. Up-regulation of PR gene expression in BABA-treated plants showed also the effectiveness of BABA to induce resistance not only against abiotic or biotic stress but also against a combination of both. There is a transition from early to later time points in the induction of genes. ABA-related genes seem to be more induced at the beginning ( $8 \mathrm{hpi}$ ) and followed by a down-regulation while the SA-dependent PR genes behave in an opposite manner. Plant defenses are dynamic and change along the time of infection. The results reported in this study could be reproduced on other crops, at different growth stages and other combined challenges to better understand the impact of BABA on plant defensive response.

\section{References}

1. FAOSTAT. http://faostat3faoorg/home/E. 2013.

2. Raiola A, Rigano MM, Calafiore R, et al. Enhancing the health-promoting effects of tomato fruit for biofortified food. Mediators Inflamm. 2014;2014:1-16.

3. Gerszberg A, HnatuszkoKonka K. Tomato tolerance to abiotic stress: a review of most often engineered target sequences. Plant Growth Regul. 2017;83(2):175-98.

4. Asselbergh B, Curvers K, Franc SC, et al. Resistance to Botrytis cinerea in sitiens, an Abscisic Acid-Deficient tomato mutant, involves timely production of hydrogen peroxide and cell wall modifications in the epidermis. Plant Physiol. 2007;144(4):1863-77.

5. Boddy L. Pathogens of autotrophs. The fungi,(3rd edition). Academic press. 2016;245-92.

6. Govrin EM, Rachmilevitch S, Tiwari BS, et al. An elicitor from Botrytis cinerea induces the hypersensitive response in Arabidopsis thaliana and other plants and promotes the gray mold disease. Phytopathology. 2006;96(3):299-307.

7. Dean R, Van Kan JAL, Pretorius ZA, et al. The Top 10 fungal pathogens in molecular plant pathology. Mol Plant Pathol. 2012;13(4):414-30.

8. Van Kan JKL. Licensed to kill: the lifestyle of a necrotrophic plant pathogen. Trends Plant Sci. 2006; 11(5): 247-53.

9. Mazid M, Khan TA, Mohammad F. Role of secondary metabolites in defense mechanisms of plants. Biology and Medicine. 2011;3(2):232-49.

10. Atkinson N, Urwin PE. The interaction of plant biotic and abiotic stresses: from genes to the field. J Exp Bot. 2012;63(10):3523-43.

11. Rasmussen S, Barah P, Suarez-Rodriguez MC, et al. Transcriptome responses to combinations of stresses in Arabidopsis. Plant Physiol. 2013;161(4):1783-94.

12. Kissoudis C, van de Wiel C, Visser RGF, et al. Enhancing crop resilience to combined abiotic and biotic stress through the dissection of physiological and molecular crosstalk. Front Plant Sci. 2014;5(207):1-20. 
13. Mickelbart MV, Hasegawa PM, Bailey-Serres J. Genetic mechanisms of abiotic stress tolerance that translate to crop yield stability. Nat Rev Genet. 2015;16(4):237-51.

14. Fujita M, Fujita Y, Noutoshi Y, et al. Crosstalk between abiotic and biotic stress responses: a current view from the points of convergence in the stress signaling networks. Curr Opin Plant Biol. 2006;9(4):436-42.

15. Niinemets U. Responses of forest trees to single and multiple environmental stresses from seedlings to mature plants: past stress history, stress interactions, tolerance, and acclimation. Forest Ecol Manag. 2010;260(10):1623-39.

16. Verma V, Ravindran P, Kumar PP. Plant hormone-mediated regulation of stress responses. BMC Plant Biol. 2016;16(1): 86.

17. Narusaka Y, Narusaka M, Seki M, et al. Crosstalk in the response to abiotic and biotic stresses in Arabidopsis: analysis of gene expression in cytochrome P450 gene superfamily by cDNA microarray. Plant Mol Biol. 2004;55(3):327-42.

18. Goel AK, Lundberg D, Torres MA, et al. The Pseudomonas syringae type III effector HopAM1 enhances virulence on water-stressed plants. Mol Plant-Microbe Ineract. 2008;21(3):361-70.

19. Wang Y, Bao ZL, Zhu Y, et al. Analysis of temperature modulation of plant defense against biotrophic microbes. Mol Plant-Microbe Interact. 2009;22(5):498-506.

20. Cho D, Shin DJ, Jeon BW, et al. ROS-mediated ABA signaling. J Plant Biol. 2009;52(2):102-13.

21. DiLeo MV, Pye MF, Roubtsova TV, et al. Abscisic acid in salt stress predisposition to phytophthora root and crown rot in tomato and Chrysanthemum. Phytopathol. 2010;100(9):871-9.

22. Diourte M, Starr JL, Jeger MJ, et al. Charcoal rot (Macrophomina phaseolina) resistance and the effects of water stress on disease development in sorghum. Plant Pathol. 1995;44(1):196-202.

23. Mayek-Pérez N, García-Espinosa R, López-Castañeda C, et al. Water relations, histopathology and growth of common bean (Phaseolus vulgaris L) during pathogenesis of Macrophomina phaseolina under drought stress. Physiol Mol Plant Pathol. 2002;60(4):185-95.

24. Mohr PG, Cahill DM. Abscisic acid influences the susceptibility of Arabidopsis thaliana to Pseudomonas syringae pv Tomato and Peronospora parasitica. Funct Plant Biol. 2003; 30(4):461-69.

25. Bowler C, Fluh R. The role of calcium and activated oxygens as signals for controlling cross-tolerance. Trends Plant Sci. 2000;5(6):241-46.

26. Mittler R, Blumwald E. Genetic engineering for modern agriculture: challenges and perspectives. Ann Rev Plant Biol. 2010;61:443-62.

27. Mauch-Mani B, Mauch F. The role of abscisic acid in plantpathogen interactions. Curr Opin Plant Biol. 2005;8(4): 409-14.
28. Ton J, En VDS, Hulten VM, et al. Priming as a mechanism behind induced resistance against pathogens, insects and abiotic stress. IOBC/wprs Bull. 2009;44:3-13.

29. Abou Qamar S, Chen X, Dhawan R, et al. Expression profiling and mutant analysis reveals complex regulatory networks involved in Arabidopsis response to Botrytis infection. Plant J. 2006;48(1):28-44.

30. Achuo EA, Prinsen E, Hofle M. Influence of drought, salt stress and abscisic acid on the resistance of tomato to Botrytis cinerea and Oidium neolycopersici. Plant Pathol. 2006;55(2):178-86.

31. Audenaert K, De Meyer GB, Hofte M. Abscisic acid determines basal susceptibility of tomato to Botrytis cinerea and suppresses salicylic acid-dependent signaling mechanisms. Plant Physiol. 2002;128(2):491-501.

32. Ramegowda V, Senthil-Kumar M. The interactive effects of simultaneous biotic and abiotic stresses on plants: mechanistic understanding from drought and pathogen combination. J Plant Physiol. 2015;176:47-54.

33. Mehdy MC. Active oxygen species in plants defense against pathogens. Plant Physiol. 1994;105(2): 467-72.

34. Koussevitzky S, Suzuki N, Huntington S, et al. Ascorbate Peroxidase 1 Plays a Key Role in the Response of Arabidopsis thaliana to Stress Combination. J Biol Chem. 2008;283(49):34197-203.

35. Gill SS, Tuteja N. Reactive oxygen species and antioxidant machinery in abiotic stress tolerance in crop plants. Plant Physiol Biochem. 2010;48(12):909-30.

36. Mittler R. Oxidative stress, antioxidants and stress tolerance. Trends Plant Sci. 2002;7(9):405-10.

37. Apel K, Hirt H. Reactive oxygen species: metabolism, oxidative stress, and signal transduction. Annu Rev Plant Biol. 2004;55:373-99.

38. Miller G, Suzuki N, Ciftci-Yilmaz S, et al. Reactive oxygen species homeostasis and signalling during drought and salinity stresses. Plant Cell Environ. 2010;33(4):453-67.

39. Malolepsza U, Urbanek H. o-Hydroxyethylorutin-mediated enhancement of tomato resistance to Botrytis cinerea depends on a burst of reactive oxygen species. J Phytopathol. 2002;150(11-12):616-24.

40. Unger C, Kleta S, Jandl G, et al. Suppression of the defence-related oxidative burst in bean leaf tissue and bean suspension cells by the necrotrophic pathogen Botrytis cinerea. J Phytopathol. 2005;153(1):373-8.

41. Torres MA. ROS in biotic interactions. Physiol Plant. 2010;138(4):414-29.

42. Laluk K, AbuQamar S, Mengiste T. The Arabidopsis mitochondria-localized Pentatricopeptide Repeat Protein PGN functions in defense against necrotrophic fungi and abiotic stress tolerance. Plant Physiol. 2011;156(4): 2053-68.

43. Conrath U, Pieterse CM, Mauch-Mani B. Priming in plantpathogen interactions. Trends Plant Sci. 2002;7(5):210-16.

44. Balmer A, Pastor V, Gamir J, et al. The 'prime-ome': towards a holistic approach to priming. Trends Plant Sci. 2015;20(7):443-52. 
Citation: Rejeb IB, Pastor V, Mauch-Mani B, et al. Impact of $\beta$-aminobutyric acid on induced resistance in tomato plants exposed to a combination of abiotic and biotic stress. J Agric Sci Bot 2018;2(3):12-23.

45. Ton J, Jakab $\mathrm{G}$, Toquin $\mathrm{V}$, et al. Dissecting the $\beta$ aminobutyric acid induced priming phenomenon in Arabidopsis. Plant Cell. 2005;17(3):987-99.

46. Cohen Y, Moshe M, Mauch-Mani B. BABA-induced resistance: milestones along a 55-year journey. Phytoparasitica. 2016;44:513-38.

47. Ton J, Mauch-Mani B. Beta-amino-butyric acid-induced resistance against necrotrophic pathogens is based on ABAdependent priming for callose. Plant J. 2004;38(1):119-30.

48. Jakab G, Ton J, Flors V, et al. Enhancing Arabidopsis salt and drought stress tolerance by chemical priming for its abscisic acid responses. Plant Physiol. 2005;139(1):267-74.

49. Macarisin D, Wisniewski ME, Bassett C, et al. Proteomic analysis of $\beta$-aminobutyric acid - induction of drought resistance in crabapple (Malus pumila): effect on general metabolism, the phenylpropanoid pathway and cell wall enzymes. Plant Cell Environ. 2009;32(11):1612-31.

50. Faghani E, Gharechahi J, Komatsu S, et al. Comparative physiology and proteomic analysis of two wheat genotypes contrasting in drought tolerance. J Proteomics. 2015;114:1-15.

51. Oka Y, Cohen Y, Spiegel Y. Local and systemic induced resistance to the root-knot nematode in tomato by DL- $\beta$ Amino-n-butyric acid. Phytopathological. 1999;89(12): 1138-43.

52. Thordal-Christensen H, Zhang ZG, Wei YD, et al. Subcellular localization of $\mathrm{H} 2 \mathrm{O} 2$ in plants. $\mathrm{H} 2 \mathrm{O} 2$ accumulation in papillae and hypersensitive response during the barley-powdery mildew interaction. Plant J. 1997;11(6):1187-94.

53. Luna E, Pastor V, Robert J, et al. Callose Deposition: A Multifaceted Plant Defense Response. Mol Plant-Microbe Interact. 2011;24(2):183-93.

54. Roth R, Boudet AM, Pont-Lezic R. Lignification and cinnamyl alcohol dehydrogenase activity in developing stems of tomato and poplar: a spatial and kinetic study through tissue 2. J Exp Bot. 1997;48(2):247-54.

55. Sanchez-Aguayo I, Rodriguez-Galan JM, Garcia R, et al. Salt stress enhances xylem development and expression of S-adenosyl-L-methionine synthase in lignifying tissues of tomato plants. Physiol Plantarum. 2004;220(2):278-85.

56. Gorvin EM, Levine A. Infection of Arabidopsis with a necrotrophic pathogen, Botrytis cinerea, elicits various defense responses but does not induce systemic acquired resistance (SAR). Plant Mol Biol. 2002;48(3):267-76.

57. Oh SJ, Song SI, Kim YS, et al. Arabidopsis CBF3/ DREB1A and ABF3 in transgenic rice increased tolerance to abiotic stress without stunting growth. Plant Physiol. 2005;138(1):341-51.

58. Nakashima k, Yamaguchi-Shinozaki K, Shinozaki K. The transcriptional regulatory network in the drought response and its crosstalk in abiotic stress responses including drought, cold, and heat. Front Plant Sci. 2014;5(170):1-7.

59. Joshi R, Wani SH, Singh B, et al. Transcription Factors and Plants Response to Drought Stress: Current Understanding and Future Directions. Front Plant Sci. 2016;7:1-15.
60. Lawton KA, Friedrich L, Hunt M, et al. Benzothiadiazole induces disease resistance in Arabidopsis by activation of the systemic acquired resistance signal transduction pathway. Plant J. 1996;10(1):71-82.

61. Pye MF, Hakuno F, MacDonald JD, et al. Induced resistance in tomato by $\mathrm{SAR}$ activators during predisposing salinity stress. Front Plant Sci. 2013;4:1-9.

62. Yasuda M, Ishikawa A, Jikumaru Y, et al. Antagonistic Interaction between Systemic Acquired Resistance and the Abscisic Acid-Mediated Abiotic Stress Response in Arabidopsis. Plant Cell. 2008;20(6):1678-92.

63. Uknes S, Mauch-Mani B, Moyer M, et al. Acquired resistance in Arabidopsis. Plant Cell. 1992;4(6):645-56.

64. Kissoudis C, Sunarti S, van de Wiel C, et al. Responses to combined abiotic and biotic stress in tomato are governed by stress intensity and resistance mechanism. J Exp Bot. 2016;67(17):5119-32.

65. Henfling JWDM, Bostock R, Kuc J. Effect of abscisic acid on rishitin and lubimin accumulation and resistance to Phytophthora infestans and Cladosporium cucumerinum in potato tuber tissue slices. Phytopathol. 1980;70(11):1074-8.

66. Koga H, Dohi K, Mori M. Abscisic acid and low temperatures suppress the whole plant-specific resistance reaction of rice plants to the infection of Magnaporthe grisea. Physiol Mol Plant Pathol. 2004;65(1):3-9.

67. Thaler JS, Bostock RM. Interactions between abscisic acidmediated responses and plant resistance to pathogens and insects. Ecology. 2004;85(1):48-58.

68. Enright S, Cipollini D. Infection by powdery mildew Erysiphe cruciferarum (Erysiphaceae) strongly affects growth and fitness of Alliaria petiolata (Brassicaceae). Am J Bot. 2007;94(11):1813-20.

69. Pastor V, Luna E, Ton J, et al. Fine tuning of reactive oxygen species homeostasis regulates primed immune responses in Arabidopsis. Mol Plant-Microbe Interact. 2013;26(11):1334-44.

70. Cohen Y, Reuveni M, Baider A. Local and systemic activity of BABA (DL-3-aminobutyric acid) against Plasmopara viticola in grapevines. Eur J Plant Pathol. 1999;105(4):351-61

71. Hamiduzzaman MM, Jakab G, Barnavon L, et al. Betaaminobutyric acid-induced resistance against downy mildew in grapevine acts through the potentiation of callose formation and jasmonic acid signaling. Mol Plant-Microbe Interact. 2005;18(8):819-29.

72. Flors V, Ton J, Van Doorn R, et al. Interplay between JA, $\mathrm{SA}$ and $\mathrm{ABA}$ signaling during basal and induced resistance against Pseudomonas syringae and Alternaria beassicicola. Plant J. 2007;54(1):81-92.

73. Flors V, Ton J, Jakab G, et al. Abscisic acid and callose: team players in defense against pathogens? J Phytopathol. 2005; 153(7-8):377-83.

74. Wiese J, Kranz T, Schubert S. Induction of pathogen resistance in barley by abiotic stress. Plant Biol. 2004;6(5): 529-36. 
75. Xiong LM, Schumaker KS, Zhu J-K. Cell signaling during cold, drought, and salt stress. Plant Cell. 2002;14(S1):S165S83.

76. Zhu JK. Salt and drought stress signal transduction in plants. Annu Rev Plant Biol. 2002;53(1):247-73.

77. Maruyama K, Todaka D, Mizoi J, et al. Identification of cis-acting promoter elements in cold-and dehydration induced transcriptional pathways in Arabidopsis, rice, and soybean. DNA Res. 2011;19(1): 37-49.

78. Fujita Y, Fujita M, Shinozaki K, et al. ABA mediated transcriptional regulation in response to osmotic stress in plants. J Plant Res. 2011;124(4):509-25.

79. Fujita Y, Yoshida T, Yamaguch-Shinozaki K. Pivotal role of the AREB/ABF-SnRK2 pathway in ABRE-mediated transcription in response to osmotic stress in plants. Physiol Plantarum. 2012;147(1):15-27.

80. Sah SK, Reddy KR, Li J. Abscisic acid and abiotic stress tolerance in crop plants. Front Plant Sci. 2016;7(571):1-26.

81. Barbosa EGG, Leite JP, Marin SRR, et al. Overexpression of the ABA-Dependent AREB1 transcription factor from Arabidopsis thaliana improves soybean tolerance to water deficit. Plant Mol Biol Rep. 2012; 31(3):719-30.

82. Yoshida T, Fujita Y, Maruyama K, et al. Four Arabidopsis $\mathrm{AREB} / \mathrm{ABF}$ transcription factors function predominantly in gene expression downstream of SnRK2 kinases in abscisic acid signalling in response to osmotic stress. Plant Cell Environ. 2014;38(1):35-49.

83. Wang J, Liu X, Zhang X, et al. Size and variability of crop productivity both impacted by $\mathrm{CO} 2$ enrichment and warming-A case study of 4 year field experiment in a Chinese paddy. Agric Ecosys Environ. 2016;221:40-9.

84. Iwaki T, Guo L, Ryals JA, et al. Metabolic profiling of transgenic potato tubers expressing Arabidopsis dehydration response element-binding protein 1A (DREB1A). J Agric Food Chem. 2013;61(4):893-900.

85. Shavrukov Y, Baho M, Lopato S, et al. The TaDREB3 transgene transferred by conventional crossings to different genetic backgrounds of bread wheat improves drought tolerance. Plant Biotechnol J. 2015;14(1):313-22.

86. Augustine SM, Ashwin Narayan J, Syamaladevi DP, et al. Overexpression of EaDREB2 and pyramiding of EaDREB2 with the pea DNA helicase gene (PDH45) enhance drought and salinity tolerance in sugarcane (Saccharum spp hybrid). Plant Cell Rep. 2014;34(2):247-63.

87. Chen H, Liu L, Wang L, et al. VrDREB2A, a DREBbinding transcription factor from Vigna radiata, increased drought and high salt tolerance in transgenic Arabidopsis thaliana. J Plant Res. 2015;129(2):263-73.

88. Orellana S, Yanez M, Espinoza A, et al. The transcription factor SIAREB1 confers drought, salt stress tolerance and regulates biotic and abiotic stress-related genes in tomato. Plant Cell Environ. 2010;33(12):2191-208.

89. Oraby H, Ahmad R. Physiological and biochemical changes of $\mathrm{CBF} 3$ transgenic oat in response to salinity stress. Plant Sci. 2012;185-186:331-9.
90. Zandkarimi H, Ebadi1 A, Salami SA, et al. Analyzing the expression profile of $\mathrm{AREB} / \mathrm{ABF}$ and $\mathrm{DREB} / \mathrm{CBF}$ genes under drought and salinity stresses in grape (Vitis vinifera L). PLOS ONE. 2015;10(7):e0134288.

91. Mostek A, Borner A, Weidner S. Comparative proteomic analysis of $\beta$-aminobutyric acid-mediated alleviation of salt stress in barley. Plant Physiol Biochem. 2016;99:150-61.

92. Song Y, Zhang C, Ge W, et al. Identification of $\mathrm{NaCl}$ stressresponsive apoplastic proteins in rice shoot stems by $2 \mathrm{D}$ DIGE. J Proteomics. 2011;74(7):1045-67.

93. Chojak-Kozniewska J, Linkiewicz A, Sowa S, et al. Interactive effects of salt stress and Pseudomonas syringae pv lachrymans infection in cucumber: Involvement of antioxidant enzymes, abscisic acid and salicylic acid. Environ Exp Bot. 2017;136:9-20.

94. Seo PJ, Park CM. MYB96-mediated abscisic acid signals induce pathogen resistance response by promoting salicylic acid biosynthesis in Arabidopsis. New Phytol. 2010;186(2): 471-83.

95. Thevenet D, Pastor V, Baccelli I, et al. The priming molecule b-aminobutyric acid is naturally present in plants and is induced by stress. New Phytol. 2016;213(2):552-9.

96. Baccelli I, Glausser G, Mauch-Mani B. The accumulation of b-aminobutyric acid is controlled by the plant's immune system. Planta. 2017;246(4):791-96.

97. Sagi M, Fluhr R. Production of reactive oxygen species by plant NADPH oxidases. Plant Physiol. 2006;141(2):336-40.

98. Seifi A, Gao D, Zheng Z, et al. Genetics and molecular mechanisms of resistance to powdery mildews in tomato (Solanum lycopersicum) and its wild relatives. Eur J Plant Pathol. 2013;138(3):641-65.

99. Bai Y, Kissoudis C, Yan Z, et al. Plant behaviour under combined stress: tomato responses to combined salinity and pathogen stress. Plant J. 2018;93 (4):781-93.

100Sivakumaran A, Akinyemi A, Mandon J, et al. ABA suppresses Botrytis cinerea elicited NO production in tomato to influence $\mathrm{H} 2 \mathrm{O} 2$ generation and increase host susceptibility. Front Plant Sci. 2016;7(709):1-12.

101Noctor G. Metabolic signaling in defense and stress: The central roles of soluble redox couples. Plant Cell Environ. 2006;29(3):409-25.

102Singh LP, Gill SS, Tuteja N. Unraveling the role of fungal symbionts in plant abiotic stress tolerance. Plant Signal Behav. 2011;6(2):175-91.

\section{*Correspondence to:}

Brigitte Mauch-Mani

Laboratory of Molecular and Cell Biology

University of Neuchâtel,

Rue Emile-Argand 11, 2009 Neuchâtel

Switzerland

E-mail: brigitte.mauch@unine.ch 